\title{
FINANCIAL AUDIT AS A PART OF STATE ADMINISTRATION IN UKRAINE: CONDITION AND PUBLIC NEED
}

\author{
Sergey BARDASH ${ }^{1}$, Yurii BARANIUK ${ }^{2}$ \\ Kyiv National University of Trade and Economics, Ukraine
}

\begin{abstract}
Economic development of countries leads to the need improving the quality of public administration, the results of which provide economic growth, social prosperity and are facilitating to solve global problems that are facing humanity. To improve the efficiency of public administration should be effective monitoring system that can detect deviations from the planned strategic development goals, unseemly level of its operation determines the target of work, which is to establish the condition of the state financial audit in Ukraine and the definition of new uncontrollable earlier objects which are managed the state apparatus, the identification of which will improve the functionality of the system of state financial audit in Ukraine. In order to achieve the goals you need to solve the following tasks. First, should set a condition of the state economic management in Ukraine and determine the public authorities, which are subjects to implementing control functions of public administration. Second, determine the resources that have the public interest and should be controlled by the state. Third, determine the composition of objects and install a condition of government auditing system in order to improve the efficiency of these next control measures of the Accounting Chamber of Ukraine and the State Audit Service of Ukraine. The methodological basis of the study is the dialectical method, which is to implement research of financial audit in public administration, its relationship with other forms of control exercised by the state; systematic analysis of financial and economic processes, which is carrying out researching of the state financial audit in the system of relations arising between economic entities of the public and private sectors; methods of retrospective and comparative analysis of experience within the objective focus in the organization of state financial audit on the territory of Ukraine; evaluation and generalization which consists of summarize the results and development proposals of improvement of financial audit system. Scientific results of the study is to establish the condition of the state management of economy of Ukraine, which needs reform, which will can ensure the growth of socio-economic development indicators. Determined the public authorities that are subjects to implementing control functions of public administration and the resources that have the public interest and should be controlled by the state. Besides were identified the composition of objects and established the condition of functioning state government auditing system, which helped determine the content of the concept of transformation of public audit, which unlike existing is accounted a full list of its facilities and is based on scientific principles of realization. Practical meaning. The lack of an effective and efficient system of public audit as a management function does not provide the growth of social and economic standards, deepens economic crisis, which is reflected in the reduction in real incomes and economic decline of the state as a whole. Determining the condition to calculate the required amount of public financial resources as an object of state financial audit is a key condition, which allows for a fresh look at the activities of bodies which are empowered to monitor compliance with financial discipline of economic entities in Ukraine. Value/originality. Received data to determine the condition of state financial audit and management, state audit objects, components of public finances and their confrontation in order to compare and identify differences in the volume under control and actual financial resources makes it possible to assess the working results of supreme audit institutions in Ukraine.
\end{abstract}

Key words: audit of public finance, public finance, public authorities, public interest, state and local budgets.

JEL Classification: E01, H61, H83, L38, M48

\footnotetext{
Corresponding author:

${ }^{1}$ Department of Financial Audit, Kyiv National University of Trade and Economics.

E-mail: serg.bardash@gmail.com

${ }^{2}$ Department of Financial Audit Department, Kyiv National University of Trade and Economics.

E-mail: baraniukyurii@gmail.com
} 


\section{Introduction}

The relevance of the study includes the need for information that reflects the degree of effectiveness the state management of financial assets. Any capital owner, including the state, has an objective need for the transition from the familiar control which is mostly carried out by the results of financial and economic activities to a qualitatively new continuous control, the need to implement is determined by socio-economic factors. Rational management of public financial resources, accompanied by the effective control, is the key to economic stability, providing economic growth and improving social welfare. However, the current shortcomings in the national economy, including a large share of the shadow economy, corruption at the higher levels of government, composing scarce public budgets, theft and inefficient use of state property and funds, mostly can be explaining by the extremely poor condition of state financial control, the main cause of which is artificial inhibition of its scientifically justified development. The novelty of research is the scientific hypothesis that consists of the assumption of incomprehension the potential and the results of carrying out the state financial audit. The study aims to determine the condition of operation the state's financial audit system in Ukraine and the search for new objects that are at the disposal of the state management apparatus and their audit is necessary requisition for further development of society. Goals achievement will allow identifying objects of state's financial audit in relation to the condition that there is increased public interest.

\section{Management condition of public finances of Ukraine and place of state financial audit in it}

The democratization of socio-economic development, globalization processes, international economic integration, the formation of civilized market relations significantly affect the economic development of all state institutions, including the state of public administration, causing the growth of public interest in the actions of the authorities. On the other side in the state leadership there is a need for information that reflects the degree of efficiency and legitimacy of the actions with controlling objects, which leads to the emergence of state financial control institutions. Timely detection of violations of the budget process will enable to carry out a series of sequential steps that will help to prevent losses of state financial resources.

State of public financial management in Ukraine, according to international estimates is in unsatisfactory level what can be explained by constant budget deficit and the necessity of external financial assistance. Specifically indicator of economic freedom index that is calculated by Wall Street Journal and Heritage Foundation (Ukraine's economic freedom, 2015), Ukraine fell to 162 place out of 179 countries surveyed and draws up 46.9 units. It should be noted that this index, which is less than 50 units, is described the country as despotic. Moreover, the components of the index of economic freedom are: 28.0 - for public expenditure; 15.0 - freedom of investment; 30.0 - financial freedom; 20.0 - protection of property rights; 25.0 - freedom from corruption. For such low components of the index of economic freedom, it is difficult to talk about the development of the financial market and the effectiveness of public spending the government of Ukraine, which are key elements of public finance management.

World Bank Group is making its assessment of the ease of doing business in the project Doing business Ukraine (2016) and has evaluated our country on 83 place from 189 countries, indicating the adaptation of the tax system to taxpayer. Also proof of that are the high marks of free trade - 85.8; tax freedom - 78.7, which are components of the index of economic freedom (Ukraine's economic freedom, 2015).

Negative trends functioning of public financial management in Ukraine can observe from analytical studies that displayed in the reports of international organizations. On the one hand, it can be assessed positively, because a higher position in the ranking of Doing business should in theory ensure the flow of foreign investments in Ukraine, but the unacceptable performance of corruption, protection of property rights, for us won't be achievable international cooperation.

In order to organize international business and the transformation of Ukraine into the center of European trade is essential ensuring the effective functioning of government auditing system. Primarily, it is necessary to analyze violations found in previous periods and implement all necessary measures to prevent them in the future. Second, there is a need to improve public audit methodology that will identify currently unknown financial fraud schemes.

Considering results of the international assessments, audit of public finances, in particular revenues and expenditures of the state budget, is particularly necessary to improve efficiency of public finances management, reducing the shadow economy and improve the well-being of society.

In our opinion, the most important consequence of the formed modern state of the system of financial audit in Ukraine is features of the transition process to market relations with the proclamation of independence. It should be noted that had the need to maintain a certain degree of state intervention in the economy because: «the market and the market economy does not guarantee a balance of economic, political and social development. First, the fundamental structural changes in the economy, solving a number of global problems are possible not on the basis of market incentives, but exclusively at the expense of public programming. Second, market regulation of something isn't often perfectly. In particular, it is unable to solve social problems and the problem of non-production sphere. So anywhere are used embedded controllers that adjust the operation of the market. Nowhere in the world there is a 
market self-regulation in its pure form, even in a liberalized country like the United States of America. However, in this case it is important not to fall into the other extreme is the implementation of total state control. So a control should be neither insufficient nor excessive» (Bardash, monograph, 2008).

The interests of the state in the development of public sector audit of the national economy should be correlated with the actions of the government, the parliament and ensure their development and expansion of the institutional environment with the aim to be covered all financial resources which are controlled by the state. The organization level of state auditing system partly determines economic development, international cooperation and prosperity of society.

The system of state financial control and bodies, which are carried out by it, are looked by E.V. Mnich (2009), Y.B. Slobodyanyk (2014), I.A. Angelina (2014) and other researchers, but due to the reorganization of certain institutions and organizations the results of their research partly lost its relevance. In Ukraine, the system of financial control as a function of state management is represented by the following bodies that have certain supervisory powers (Fig. 1).

The main specially authorized bodies in public administration, which are empowered to conduct state financial audit is the State Audit Service of Ukraine and the Accounting Chamber of Ukraine. It should be noted that the constant reorganization of government financial control is not conducive to satisfy full control of all state financial resources. As for the parliamentary financial audit, the feature of carrying out is the control of money resources in established list of enterprises, institutions and organizations who are administrators or recipients of budget funds. Moreover, quite often the activity of the same entities is becoming an object for simultaneously monitoring by governmental and parliamentary bodies of financial control. The most interesting is that the content

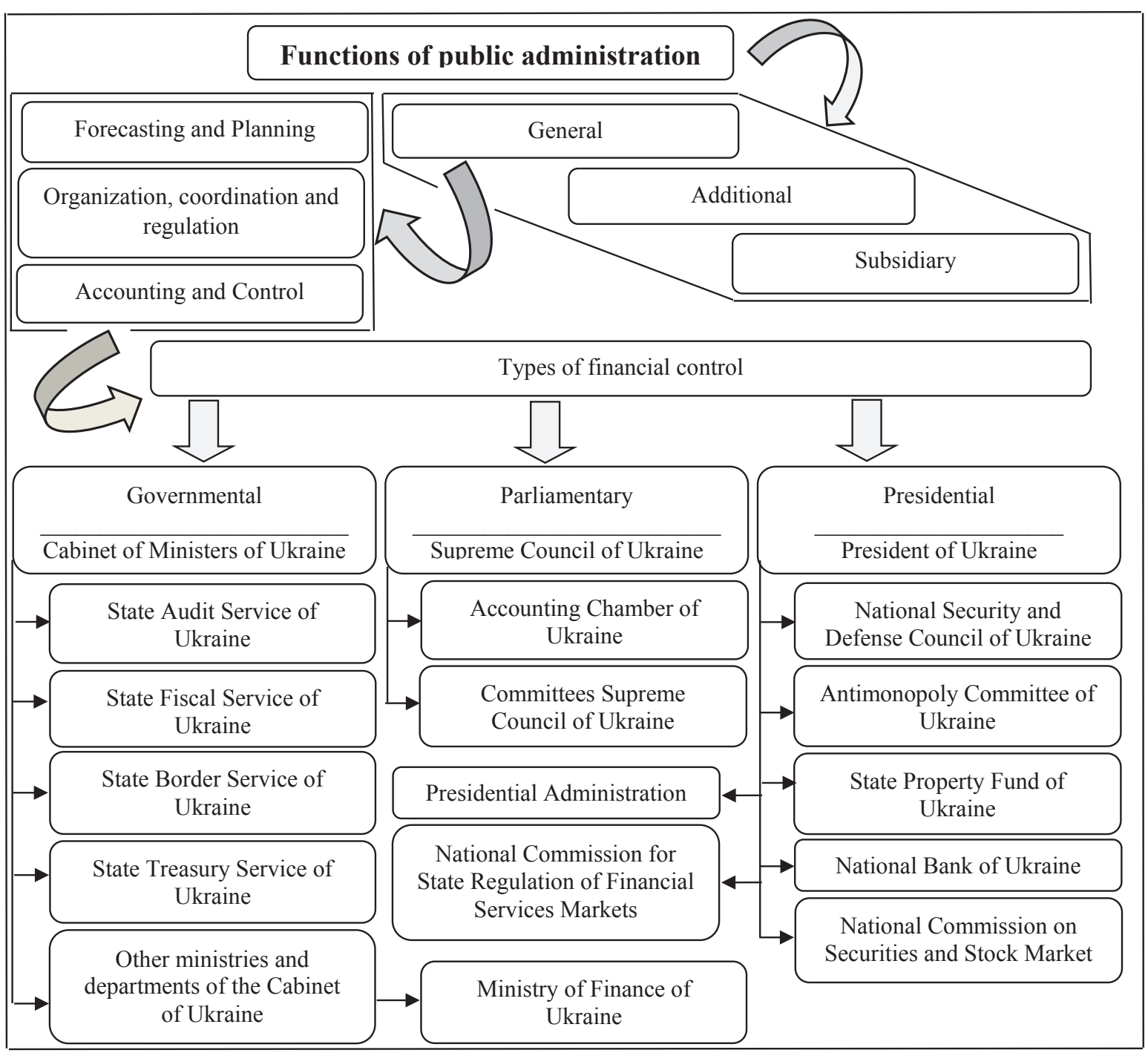

Fig. 1. Types of financial control as the functions of state management and authorities that implement them Source: developed by the authors 
of the audit procedures do not differ significantly, but the results of them are different.

Thus, the state of public administration in Ukraine is in poor condition, due to macroeconomic instability, which is largely caused by external interstate relations that have developed in recent years. It should be noted that along with the impact of external factors there are internal, that have ambiguous nature and cause personnel changes in the system of governance that according affect on the strategy of socio-economic development of Ukraine. In order to minimize the impact of internal factors need to increase the quantity and improve the quality of control measures, which are an integral part of public administration. Moreover, there should make distinction authorities of monitoring between branches of power, which in turn will improve the performance of audit procedures by the resources growth, which are checked.

\section{Objects of state financial audit}

In the development process of the states' economies, transition to market relations and the weakening role of the state in social relations, there appears a necessary to state regulation of certain sectors of the economy that do not have a supportive environmental for self-sufficiency. Lack of support of periodically unprofitable sectors of the economy leads to the «sectoral unemployment», the reduction in amount of consumption and the deepening financial crisis in some countries.

Public administration should be planned; in particular this is demanded success stories of the most successful countries in a world. The transition to program-oriented method of social management involves a long-term cooperation of public authorities with economic subjects which are regarded to the expenditure of financial funds. Rightness, legality and efficiency - the basic principles that ensure the success of relationships that arise between administrators and recipients of budgetary funds.

Audit of state finances as a special kind of state financial control is called to ensure compliance with the above principles by conducting audit activities. Particularly controversial and unresolved issue is identification objects of the state financial audit.

Without establishing clear list of objects of state audit causes the detection impossibility a part of the cash flows related to governance. Moreover, the strategy chosen by the State Audit Service of Ukraine which lies to reduce the list of companies, organizations and institutions whose activities are subject to public audit and brings about a loss of control over the activities of the state sector of the economy that threatens the future condition of Ukraine economy.

Reducing the number of businesses, organizations and institutions that must be supervised by the State Audit Service of Ukraine weakens the state financial control on the part of the Cabinet of Ministers of Ukraine. On the other hand, a reduction in the number of employees of the Accounting Chamber of Ukraine what is a result of changes adopted in the new Law of Ukraine «About the Accounting Chamber of Ukraine» (2015). The changes above destroying the system of state financial audit, leading to financial losses of state and prevents real understanding valid and existent financial balance of Ukraine.

Extremely important is establishing a list of objects which must be controlled by the state that have a national interest. Problems related to the scientific substantiation object state audit are evident in the works of many homeland scholars.

Objects of state audit as defined in the work O.Y. Pushkareva (2009) consist entities of the public sector and other entities that receive funds from the state and local budgets or carry out exploitation of state or municipal property.

In our view, the position of O.Y. Pushkareva (2009) doesn't fully reveals the components objects of state audit, as it doesn't contain information that describes the formation of public funds of money.

According to J.B. Slobodianyk (2013), the objects of state financial audit include economic activities of public authorities and other entities related to the formation, distribution and use of public resources.

An interpretation of objects of the state financial audit submitted in labor Y.B. Slobodianyk (2013) reveals wider the essence of directivity ongoing state audit activities.

On mind O.A. Scorba (2010), the objects of state financial audit is the activity and function of public authorities, budgetary institutions and organizations recipients of public funds, state or municipal property and public sector entities of the economy, and so on.

Another approach to the separation of objects of the state financial audit is applied by V.F. Maksimov (2013), who selected:

- financial resources and property of the state, their accounts;

- draft laws and regulations;

- assessment of the financial results of the budget;

- valuation of prognosis and trends of separate industries, regions and the state as a whole.

The importance of information and usefulness of the approach, published by V.F. Maksimov (2013), is detailing the composition of objects of the state financial audit, but the assessment of financial results of the budget is more likely action as a task that is put before the bodies of state financial audit.

A similar approach to the definition of objects of state audit adheres V.P. Khomutenko (2011). The author considers such objects:

- data of accounting and reporting;

- planning documents and commercial contracts;

- system of internal financial control;

- Government loans and borrowings what are given under guaranteed by the government of Ukraine;

- funds provided from the state budget and local budgets, and (or) target national funds for the implementation of public tasks, implementation of national budget programs; 
- state and municipal property, natural resources and other state resources;

- activities and functions of public authorities, budgetary institutions and organizations - recipients of budget funds, state or municipal property and entities in the public sector.

We are convinced that an identification of the integrated facility of state financial audit should be applied the approach outlined in the previously published article (S.V. Bardash, 2008), according to which established a clear division between the object and the subject of control and there is substantiated the expediency of allocation integrated facility of state control.

Analysis of scientific views regarding identification of the state's financial audit objects indicates the existence of uncertainty concerning the need comprehensive independent review communal ownership of resources. There is a significant amount of resources in the gross domestic product of Ukraine. In particular, by final consumption GDP Ukraine finance municipal ownership accounted for $12.9 \mathrm{bln}$. UAH or $0.8 \%$ of Ukraine's GDP in 2014, compared with total consumption of the state sectorthat consumption was 296.2 billion. UAH representing $18.7 \%$ of Ukraine's GDP in 2014 (State Statistics Service of Ukraine, 2014). In the case of comparison consumption value of public and communal sector utility - the latter was $4.17 \%$ of the joint volume in 2014 .

Therefore, without existence single approach to the definition of objects of the state financial audit this makes impossible effective governance and control of financial resources funds. Theoretical definitions explanation and determine composition objects of the state financial audit will contribute to assessing the amount of controlled state resources, ensuring herewith the level of confidence to state governance.

\section{State audit of public finances in Ukraine, its condition and components}

Development of state governance leads to the emergence of public finance in which, in our opinion, should understand the socio-economic relations, arising from the formation, distribution (redistribution) and the use of public funds associated with satisfaction all kinds of public interest and regulated by establish mandatory requirements of state or local governments, which are distributed to the participants of economic relations of all forms of ownership. It is very important to establish components of public finances, since without single approach to classification does not allow goal oriented and object oriented carrying out of the state financial audit.

Given the characteristics of the organization budgetary system Ukraine, in our view, should define the following components of public finances, which must be an object to government audit (Fig. 2). The approach also allows to prioritize performance of the state financial audit, as reflects the amount of the main components of the state budget as components of public finance (statistical information were obtained from official data of the Law of Ukraine «About State Budget $\gg, ~ 2005,2010,2015$ ).

Public finance as an object of financial government audit includes:

1) publicstatefinances, the amount of which willbeequaled the sum of the revenue and expenditure of the state budget of Ukraine and the Pension fund of Ukraine (see figure 2). The funds mentioned in this group of public finances have the most public interest in the process of accumulation, distribution (redistribution) and use; moreover any change in the proportion of components in the budget should be scientifically justified and understandable to the public. For example, the growing share of intergovernmental transfers shows the decentralization processes in Ukraine, the growth of economic independence of regions, causing locally increased the volume of financial flows to balance individual budgets. In particular it is possible to notice increasing in the share of current expenditure in the State Budget of Ukraine, which indicates a lack of strategic development and suggests «eating away the budget»;

2) public private finances (finance small businesses, corporate finance, finance banks, finance non-profit organizations) funds of money as an intangible form consequence of relationship that arise between state, local government, private business entities and public organizations in a part of their use, the amount of which will equal the sum of the gross domestic product for the relevant period (see figure 3).

Public state finance, what are presented cash resources of the state budget consist of revenue and expenditure parts. Regarding public private finances, their sum is actually equal to the amount of the gross domestic product for the period. The sum of these components of public finances for the period 2010-2015 for purposes of state financial audit is shown in Figure 3.

Comparing the results of the financial audit activities which are carrying out by the Accounting Chamber of Ukraine and the State Audit Service of Ukraine, it should be noted that their number tends to decrease, whereas the volume of public finance for the purpose of state financial audit is increasing. The data on the figure 3 also show that volume of revealed financial violations ranged from $0.067 \%$ to $3.3 \%$ relative to the amount of public finance in Ukraine during 2010-2014. Moreover, there is a large amount of public financial resources which are owned by the state enterprises institutions and organizations, and a term of their exploitation is exceeding one year and which may partly be the elements of above foregoing components of public finances. This primarily applies to a long term capital public procurement of goods and services, which are one of the areas of implementation of public expenditure, but the financial control of the storage and use of public investment into an object is not made.

Consequently, public finances manifest through the socio-economic relationships that are associated with pleasure of all kinds of public interest and are regulated 


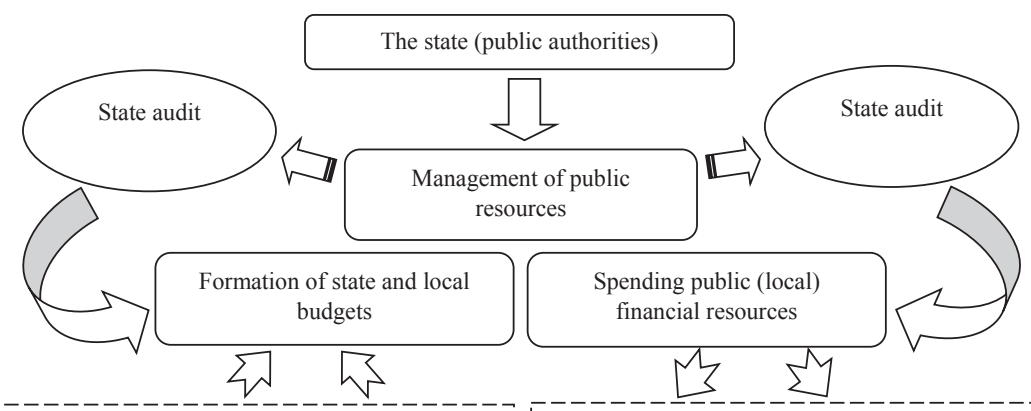

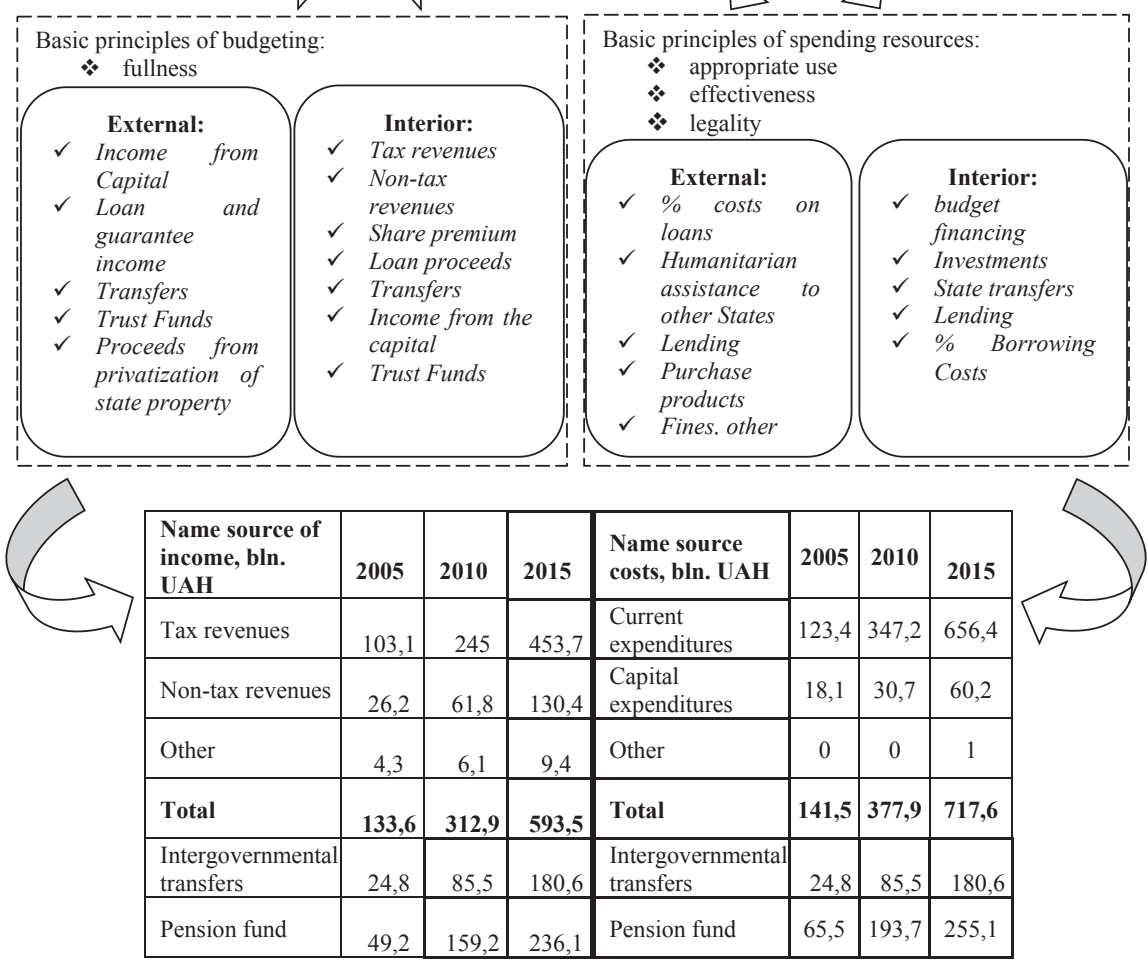

Fig. 2. The composition of public finances, which should be an object of audit as a function of the government

Source: developed by the authors

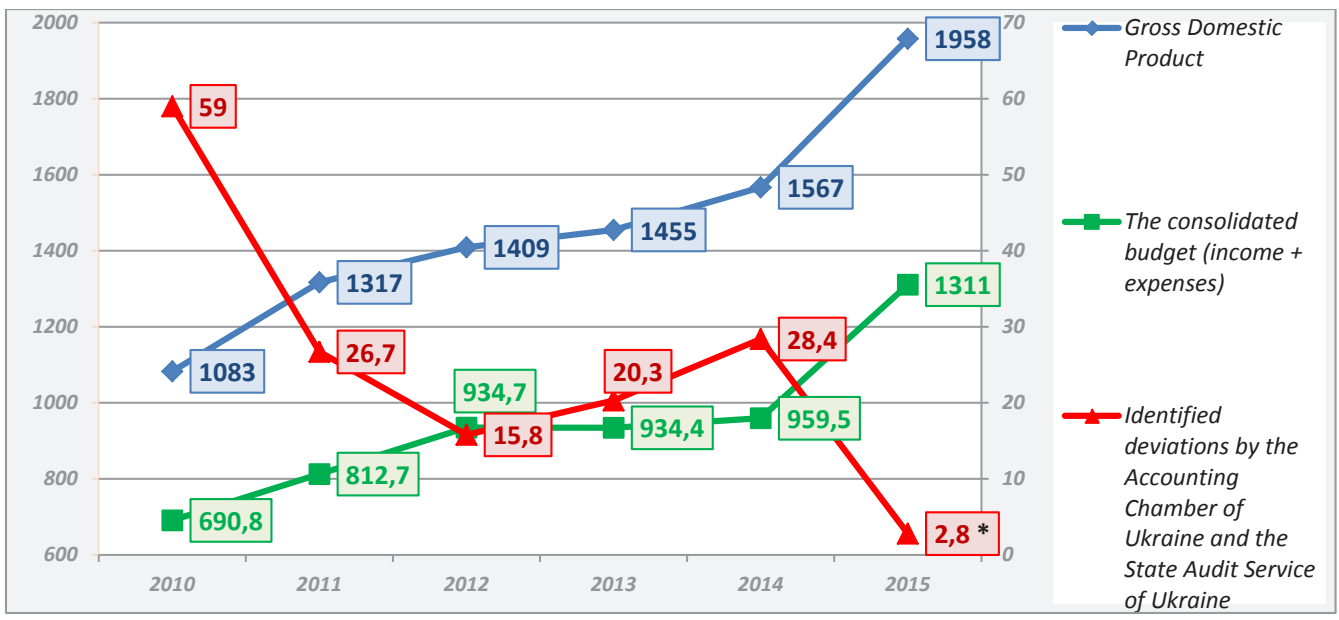

* - Identified financial resources, only the State Audit Service of Ukraine

Fig. 3. Certain macroeconomic indicators of socio-economic development of Ukraine and results of the state financial audit for 2010-2015, in billion UAH

(Compiled from official data of the State Audit Office Ukraine, the Accounting Chamber of Ukraine, the Ministry of Finance of Ukraine, internet project the «Price of the State», 2010-2015) 
by establishing mandatory requirements of state or local governments that apply to members of economic relations of all forms of ownership in the process of accumulation, distribution, redistribution and use money funds. The main components of public finances, which should be subject to public audit are public state and public private financial funds, which actually consist of revenue and expenditure of the state budget and are the basis of gross domestic product. Defining components of public finances, which should be an object to audit as a tool of government, will improve the effectiveness of control measures and will improve the state of public administration in general.

\section{Conclusions}

Public administration in Ukraine is in a difficult transition state, which is affected by influence of external and internal factors. According to international estimates socially-oriented part of state governance is virtually absent, but it created the conditions for the growth of large financial companies. To ensure the prosperity of economy and growth of the national gross domestic product, there is necessary to ensure effective control of public financial management, which should be realized in accordance with state financial policies. In a relatively short period of its activity the Accounting Chamber of Ukraine and the State Audit Service of Ukraine has managed to solve the main task - to form competent constitutional bodies, to create the basis for developing a new ideology of public, independent state financial control in Ukraine and managed to draw public attention to the false system use budget resources, show that the money of state budget money is not belong to the Government and the Ministry of Finance, but the taxpayers' money, public money means a property of every citizen's of Ukraine.
The activity of the state financial audit has limited nature, because it does not apply to all financial resources. This is due to the lack of a unified approach to the determination of state auditing objects, which prevents effective governance and doesn't allow carrying out a control of financial resources funds.

Given comparative analysis of the views of scientists about the nature of public finance and their composition, we formulated the following conclusions.

1. Public finances - social and economic relations that arise in the process of formation, distribution (redistribution) and the use of public funds that are associated with pleasure of all kinds of public interest and are regulated by establishing mandatory requirements of state or local governments that apply to members of economic relations of all forms of ownership.

2. Public Finance as an object of state financial audit include:

- public public finances (funds of the State Budget of Ukraine and local budgets, loans granted under the state and local guarantee, funds of National Bank and other stateowned banks, state trust funds, Pension Fund and funds of obligatory social insurance, funds of entities management of state and municipal property, which receive them from economic activity);

- public private finance (finance small businesses, corporate finance, finance banks, finance non-profit organizations) - funds of money as a substantive materialized form consequence of relationship that arise between state, local government, private business entities and public organizations in a part of their use.

The setting out approach to the consideration of public finance as an integrated object state financial audit will improve the efficiency of state management of public finances.

\section{References}

Angelina, I.A. (2014). Problems and prospects of forming a unified system of state financial control in Ukraine. Finance, banks, investment: research journal, Ukraine, №2, p. 9-14. Retrieved from: http://fbi.crimea.edu/ arhiv/2014/nv 2-2014/002angelina.pdf

Bardash, S.V. (2008). Control over activites of business entities: hypotheses and versions of violations. Kyiv National University of Trade and Economics, Ukraine: monograph, $312 \mathrm{p}$.

Bardash, S.V. (2008). Subject and object control as a field of scientific knowledge and practice: relationship between the categories and differences. Accounting and auditing, journal, Ukraine: number 6, p. 55-61.

Mnich, E.V., Bardash, S.V., Nykonovych, M.O., Barabash, N.S., Nazarova K.A., Olendiy O.T. (2009). State financial audit: Methodology and organization. Kyiv National University of Trade and Economics, Ukraine: monograph, 318 p. Maksimov, V.F., Slobodyanyk, Y.B. (2013). The essence of the state audit. BusinessInform Kharkiv, Ukraine: №11, p. 319-323.

Pushkareva, O.Y. (2009). The state financial audit of business entities as a priority activity of the State Control and Auditing Service. The state and the regions, Series: Economics and Business, Ukraine, №7, p. 160-164. Retrieved from: http://www.nbuv.gov.ua

Scorba, O.A. (2010). The emergence and development of state financial and economic audit. Economy: problems of theory and practice. Proceedings of Dnipropetrovsk National University, Ukraine: Issue 261, Volume V, p. 1299-1306.

Slobodyanyk, Y.B. (2013). Subject and object state audit. Bulletin of the Odessa National University. II Mechnikov, Ukraine, Volume 18, Issue 2/1, p. 154-159.

Slobodyanyk, Y.B. (2014). Formation a system of public audit in Ukraine. FOP Nataluha A., city Sumy, Ukraine: monograph, $322 \mathrm{p}$. 
Homutenko, V.P., Homutenko, A.V. (2011). Public audit as a form of financial control: the nature and institutional features. Odessa Bulletin of Social and Economic Research, Ukraine: №2 (42), p. 124-130.

Legal Project of the World Bank «Doing business Ukraine» (2015-2016). Retrieved from: http://www.doingbusiness.org/data/exploreeconomies/ukraine

Economic data by The Heritage Foundation project «Ukraine's economic freedom» (1995-2015). Retrieved from: http://www.heritage.org/index/country/ukraine

About the Accounting Chamber: Law of Ukraine (02.07.2015). №576 / 8-BP. Retrieved from: http://zakon4.rada.gov.ua/laws/show/576-19.

Analysis of the state and dynamics results of the State Statistics Service of Ukraine (2014). Retrieved from: http://www.ukrstat.gov.ua

About State Budget: Law of Ukraine (2005, 2010, 2015). Retrieved from: http://www.ligazakon.ua

Internet project «State Price»: The budget of Ukraine (2005, 2010, 2011, 2012, 2013, 2014, 2015). Retrieved from: http://cost.ua

Analysis of the state and dynamics results of the State Service of Ukraine (2010, 2011, 2012, 2013, 2014, 2015). Retrieved from: http://www.dkrs.gov.ua

Analysis of the state and dynamics results of the Accounting Chamber of Ukraine (2010, 2011, 2012, 2013, 2014). Retrieved from: http://www.ac-rada.gov.ua

Analysis of the dynamics and changes in gross domestic product of Ukraine $(2010,2011,2012,2013,2014,2015)$. Retrieved from: http://www.minfin.gov.ua

\section{Сергей БАРДАШ, Юрий БАРАНЮК}

\section{ФИНАНСОВЫЙ АУДИТ КАК СОСТАВЛЯЮЩАЯ ГОСУДАРСТВЕННОГО УПРАВЛЕНИЯ В УКРАИНЕ: СОСТОЯНИЕ И ПУБЛИЧНАЯ НЕОБХОДИМОСТЬ}

Аннотация. Развитие экономик стран мира вызывает необходимость улучшения качества государственного управления, результаты которого обеспечивают экономический рост, социальное благополучие и способствуют решению глобальных проблем, стоящие перед человечеством. Для повышения эффективности государственного управления должна существовать действенная система контроля, которая сможет выявлять отклонения от плановых стратегических целей развития, ненадлежащий уровень функционирования которой приводит чель работы, которая заключается в установлении состояния государственного финансового аудита в Украине и определении новых, учетно-неподконтрольных ранее, объектов, которые находятся в распоряжении аппарата государственного управления, идентификация которых обеспечит повышение функциональности системы государственного финансового аудита в Украине. Для достижения цели необходимо решить следующие задачи. Во-первых, следует установить состояние государственного управления экономикой Украины и определить органы государственной власти, которые являются субъектами реализации контрольной функции публичного управления. Во-вторых, определить ресурсы, которые имеют публичный интерес и должны быть подконтрольны государству. В-третьих, определить состав объектов и установить состояние функционирования системы аудита государственных финансов с целью повышения эффективности следующих контрольных мероприятий Счетной палаты Украины и Государственной аудиторской службы Украины. Методологической основой исследования является диалектический метод, который заключается в осуществлении исследования развития финансового аудита в системе государственного управления, его связи с другими формами контроля, осуществляемыми государством; системный анализ финансово-экономических процессов, который заключается в исследовании государственного финансового аудита в системе отношений, которые возникают между экономическими субъектами государственного и частного секторов экономики; методы ретроспективного и сравнительного анализа опыта объективной направленности в организации государственного финансового аудита на территории Украины; оценка и обобщение, которое заключается в подготовке результатов и разработке предложений по усовершенствованию функционирования системы государственного финансового аудита. Научные результаты исследования заключаются в установлении состояния государственного управления экономикой Украины, нуждается в реформировании, что сможет обеспечить рост показателей социально-экономического развития. Определены органы государственной власти, которые являются субъектами реализации контрольной функции публичного управления и ресурсы, которые имеют публичный интерес и должны быть контролируемые государством. Также определен состав объектов и идентифицировано состояние функционирования системы аудита государственных финансов, что позволило определить содержание концепции трансформации системы государственного аудита, 
Vol. 2, No. 2, 2016

которая в отличие от существующих учитывает полный перечень его объектов и построена на научных принципах ее проведения. Практическое значение. Отсутствие действенной и эффективной системы государственного аудита как функции управления не обеспечивает роста социально-экономических стандартов, углубляет экономический кризис, который находит свое отражение в сокращении реальных доходов граждан и экономическом упадке государства в целом. Установления состояния для определения необходимого объема финансовых публичных ресурсов как объекта государственного финансового аудита является ключевым условием, которое дает возможность по-новому посмотреть на деятельность органов, которые наделены полномочиями контролировать соблюдение финансовой дисциплины экономическими субъектами в Украине. Значение/оригинальность. Полученные данные по определению состояния государственного финансового аудита и управления, объектов государственного аудита, составляющих публичных финансов и их сопоставление с целью сравнения и выявления разницы в объеме подконтрольных и фактических финансовых ресурсов дает возможность осуществить оценку результатов работы высших органов финансового контроля в Украине. 